\title{
Public Relations or Humas: How Do the Public and Practitioners Perceive It?
}

\author{
Rachmat Kriyantono ${ }^{1 *}$ \& Choiria Anggraini ${ }^{2}$ \\ 1 Universitas Brawijaya, Jl. Veteran, Ketawanggede, Kec. Lowokwaru, Kota Malang, Jawa Timur 65145 \\ 2Telkom University, Jl. Telekomunikasi Jl. Terusan Buah Batu, Sukapura, Kec. Dayeuhkolot, Kota \\ Bandung, Jawa Barat 40257 \\ *e-mail : rachmat_kr@ub.ac.idu
}

\begin{abstract}
This study aims to describe the public and practitioner's perceptions of the public relations or Humas profession. Public relations plays a role in maintaining the credibility of the organization which is built from public perceptions. Apart from public relations, this profession is also called humas. However, based on Propechy's Self-Fulfilling Theory, it is possible to have different meanings by the public and practitioners related to these two terms. This study uses a constructivist approach (qualitative) and interview methods to collect data. The number of informants was 200 people in Malang City. The focus of this research is to find perceptions about what public relations or humas is, its functions, its relation to gender, and educational background. This research produces four propositions, namely public and practitioner perceptions of public relations and humas tends to be positive, public relations and humas are considered the same profession, men and women are perceived to be practitioners in this profession, and practitioners should come from the discipline of communication science and public relations. This research contributes to challenge the previous view that public relations is seen as an attempt to manipulate communication messages.
\end{abstract}

Keywords: Humas, public perceptions, public relations, self-fulfilling prophecy

\begin{abstract}
ABSTRAK
Penelitian ini bertujuan mendeskripsikan persepsi public dan praktisi terhadap profesi public relations atau hubungan masyarakat (Humas). Public relations berperan untuk menjaga kredibilitas organisasi yang dibangun dari persepsi-persepsi publik. Selain public relations, profesi ini juga disebut Humas. Namun, berdasarkan Teori Self-Fulfilling Propechy, dimungkinkan pemaknaan berbeda oleh public dan praktisi terkait dua istilah ini. Penelitian ini menggunakan pendekatan konstruktivistik (Kualitatif) dan metode wawancara untuk mengumpulkan data. Jumlah informan sebanyak 200 orang di Kota Malang. Fokus penelitian ini adalah menemukan persepsi tentang apa itu public relations atau Humas, fungsifungsinya, kaitannya dengan gender, dan latar pendidikan. Penelitian ini menghasilkan empat proposisi, yakni persepsi public dan praktisi terhadap public relations atau Humas cenderung positif, public relations dan Humas dianggap profesi yang sama, laki-laki dan perempuan dipersepsi dapat menjadi praktisi di profesi ini, dan praktisi sebaiknya bersal dari disiplin Ilmu Komunikasi dan kehumasan. Penelitian ini berkontribusi menantang pandangan sebelumnya bahwa public relations lebih dianggap sebagai upaya manipulasi pesan komunikasi.
\end{abstract}

Kata kunci: humas, persepsi publik, public relations, self-fulfilling prophecy 


\section{Latar Belakang}

Currently, the public relations profession in an organization is needed so that the concept of public relations is increasingly developing (Kriyantono \& McKenna, 2017; Tanyildizi \& Ataykaya, 2019; Yaxley, 2013). Public relations is able to work from low-level to top-level in an organization (Broom \& Sha, 2013). Public relations activities are directed at reducing crises, building good relations with the media, improving the reputation of the organization, handling crises, and making conflict predictions, all of which can reduce costs for the organization's operations. (Heath \& Coombs, 2006)

Public relations activities require the ability to convey information effectively, exercise persuasion, and make collaborative decisions with management (Coombs, 2015; Kriyantono, 2019a; 2019b; 2020a, 2020b). Some literature, such as Heath and Coombs (2006), and Toth (1992) calls public relations a rhetorical activity, namely the communication process for someone to influence others by processing meaning. "In keeping with the tradition of rhetoric, public relations professionals can serve society to the degree that they meet or exceed societal expectations for ethical and effective public communication. Are they good listeners? Do they appreciate others' concerns?" (Heath \& Coombs, 2006, p. 13).

Public relations activities as a rhetorical process are also supported by Broom and Sha's statement that acceptance of organizational messages is influenced by figures of public relations practitioners themselves. "To deal with communication, practitioners can craft messages that explain or reinforce organizational credibility or trustworthiness" (Broom \& Sha, 2013).

However, as a rhetorical activity, public relations is also often seen as manipulating
(Heath \& Coombs, 2006; Littlejohn et al., 2017). Public relations is indeed tasked with portraying the company as best as possible in front of the public, but the public also often perceives practitioners as propaganda which tends to be negative and manipulative (Heath \& Coombs, 2006; Kriyantono, 2017a).

The problem that arises is how then the public can receive the message attributes from public relations so that they can easily trust the information in it? Legitimacy and public trust influence the acceptance of messages conveyed by public relations, whether the public is supportive or punitive (Kriyantono et al., 2017; Kyrychok, 2017).

Furthermore, Study in US reveals that, compared to news written by journalists, news releases written by public relations practitioners were considered less honest and less persuasive through news-releases (Callison, 2014). This finding is linked to the findings of Kriyantono (2019d) who examined 32 public relations practitioners of private and government companies in East Java and found that the media relations carried out by practitioners were more focused on responding only to negative news than focusing on building long-term relationships with the media.

In fact, it is very important to build long-term relationships with the media because, according to White \& Park (2010), public perceptions are shaped by the media. The media helps to shape the public's negative perception of public relations by writing negative words and creating framing such as "public relations gimmick" and "public relations nightmare". This framing is called the second-level agenda setting (Alkazemi \& Wanta, 2018; Kiousis et al., 2016; White \& Park, 2010). Through this long-term relationship, in the end, public relations is able to influence this media framing (Kiousis et al., 2006). 
Research by Callison et al. (2014) shows a decrease in positive perceptions of the public towards public relations in US from $69.5 \%$ in 2003 to $58.2 \%$ in 2012 . This means that even though the concept of public relations is well received by the public, there is a decrease in positive perceptions in within 10 years. There is also a bad perception of public relations in Turkey (Tanyıldızı \& Ataykaya, 2019).

Apart from the negative perceptions mentioned above, several studies have also found other negative perceptions. In Indonesia, corporate public relations practitioners are perceived as a profession that relies on beauty and physical appearance, which is called lookism in public relations (Simorangkir, 2013). The standard of fashion for public relations practitioners is still determined by the patriarchal culture in Indonesia (Kriyantono \& Rakhmawati, 2020).

Some of the research above, seems to be related to the question of Fullerton \& McKinnon (2015), "Does public relations have an image problem?" This question shows that, apart from having responsibility for the image of the organization, the practitioners also have responsibility for his own image. The authors believe that negative perceptions about public relations, such as being considered dishonest, negative propaganda, and relying on physical appearance, can become obstacles to conveying persuasive messages. These negative perceptions will reduce the credibility of public relations as a communicator. Based on a rhetorical approach, the credibility is the main factor in conveying the message (Callison, 2004; Heath, 2013; Toth, 1992).

With these negative perceptions, public relations practitioners are considered to have no trustworthiness and expertise, two elements of credibility.
Since public relations is a positive presentation of an organization (Greener, 1995), it can be said that the negative credibility of public relations can make the negative credibility of the organization.

Because of this, the authors consider that Fullerton \& McKinnon's (2015) question regarding whether public relations practitioners have an image problem is still relevant to be investigated again in the Indonesian context. Despite the research of Callison et al. (2014) above found that there has been a decrease in positive perceptions, the authors believe that there is still hope for positive perceptions of the public relations profession. In addition, White and Park (2010) reveals that not all media framing of public perception corresponds to reality. In contrast, White and Park (2010) portrays that respondents still believe that public relations practitioners are responsible for controlling the crisis and do not hide the facts.

Fullerton \& McKinnon's (2015) question is also important to explore in the context of government institutions in Indonesia that have entered the era of information disclosure for 12 years. Public perceptions toward the government public relations profession have the potential to influence efforts to comply with the principle of public information disclosure in accordance with the Law number 14 of 2008, namely that public agencies have responsibilities related to providing public information service standards. Therefore, the authors formulate a research question: "How are the public's perceptions of the public relations profession?"

Several studies on public relations in Indonesia in the era of public information disclosure show an unsatisfactory portrait of public relations practices. Public relations activities still focus more on dealing with the media (Kriyantono, 
2017b). Public relations has not optimally supported the national anti-corruption program (Kriyantono et al., 2017). Public relations understanding is still low on transparency and accountability in using internet media even though the internet has been implemented to communicate with the public (Azhary \& Kriyantono, 2018). Finally, crisis management carried out by public relations has not implemented several principles in the Regulation of the Minister for Administrative Reform-Bureaucratic Reform No 29/2011 concerning crises in public relations (Kriyantono, 2019e).

On the other hand, other research has also found positive results in the practice of public relations in Indonesia, including government institutions. Symmetric communication models have begun to be found in public relations practice (Kriyantono, 2019a). Public Relations practitioners of Malang Regency have adopted ethical standards in communicating when faced with a crisis due to the Malang Regent being arrested for a corruption case (Kriyantono, 2019e).

Regarding the positive and negative results in public relations practices, the authors consider that the implementation of symmetrical communication is a very significant result to make public relations practices run even better in the future. According to the theory of excellent in public relations, which is the paradigm most widely used in research in the world (Gower, 2006; Pasadeos et al. 2010), symmetric communication is an important principle for the development of excellent public relations (Grunig et al., 2002). With the application of this symmetrical model and coupled with the era of public information disclosure, the authors conclude that public relations practices will be more effective, resulting in a more positive public perceptions of public relations.

Therefore, the authors formulate the following research assumption: Public perceptions of the public relations profession tend to be positive. To confirm the research assumption, the authors describe the public's perceptions of public relations and the perceptions of public relations practitioners themselves. The practitioners' perceptions need to be explored because, based on Merton's (1948) the Selff-Fulfilling Prophecy Theory, a person's perception of himself/herself can influence his/her behavioral tendencies. It can be said, if the practitioners want their practices to be effective, the practitioners must consider public relations profession positively.

Related to Merton's theory, the writer also examines how the informants perceive the terms "public relations" and "Humas". In Indonesia, these two terms are often used to refer to the public relations profession (; Simorangkir, 2013). Kriyantono (2017b) has used this SelfFulfilling Prophecy Theory and reveals that the practitioners who call themselves public relations have carried out communication management activities more effectively than the practitioners who refer to as "Humas". In this current research, the authors intend to follow up on Kriyantono's (2017b) study by describing public and practitioners perceptions of two terms: public relations and "Humas".

\section{Methods}

In order to answer the research problem, this study will use a constructivist approach (Associated with the term qualitative) with the interview method. The approach was chosen so that the writer can understand the phenomenon holistically, in a natural setting, and in detail because the data is in the form of words constructed by 
the informants (Daymon \& Holladay, 2011;

Kriyantono, 2020c; Neuman, 2014).

Data collection was carried out in Malang City by interviewing 200 residents of Malang City, consisting of 183 residents and seventeen public relations practitioners, members of Perhumas Malang Raya. Informants were selected using a purposive technique based on certain criteria in order to get the right source and relevant to the research objectives. Informants are citizens of Malang City, both from Malang City and those who live in Malang City for a period of approximately one year and aged 20-64 years. The criterions were expected to find informants who had an understanding of government and private institutions in Malang City and had the competence in making statements because they were all adults. Data collection was conducted from January to March 2020. This study focuses on informants' perceptions of public relations and its functions.

Data analysis was performed using analysis techniques according to Miles, Huberman, and Saldana (2014). The first stage was data collection through interviews. During the research, the resource persons meet face to face with the authors and answered the questions that had been designed previously to answer the research needs. The second stage, the authors conducted data condensation. After obtaining the data, the writer simplified, focused, and abstracted the data. The data obtained was collected and summarized in the form of descriptions.

The third stage, presentation of data. The authors presented the data against the processed data so that it was in writing. The form was then put into themes, subthemes, and ended with coding. The fourth stage, drawing conclusions and verification. The authors described the results of the sub-categories of themes, explained the results of research to answer the formulation of research problems, and made conclusions by providing supporting explanations.

\section{Findings}

In this section, the authors present the findings of the research data. Based on data analysis, the authors present them in several categories of data findings: Public and practitioners view of the public relations and Humas professions; Public relations and Humas functions; Public and practitioners view on gender issues in public relations; Public and practitioners view about the educational background of public relations; Public and practitioners view on the abilities that a public relations practitioner and Humas practitioner should have.

\section{a. Perceptions on the public relations and humas professions}

The research shows that most of the public (114 informants) said that public relations and Humas had the same concept and function, only different terms. As an informant, Rico Dwi, said, "Humas is the same as public relations. Humas is Bahasa Indonesia and public relations is English". Another informant, Zaidan, also said the same thing "The same, because Humas is the meaning of the word public relations".

Even though they stated that the concepts of public relations and Humas are the same, the public defined the concepts of public relations and Humas in various ways. There were 82 publics who defined public relations and Humas were part of an agency that liaises with the community or is associated with the community. Iwan as an online motorcycle taxi driver also conveyed the definition of public relations and public relations as follows "Covering the community, as a bridge that connects an organization with the community". In line with the explanation regarding the 
definition of public relations and Humas conveyed by another informant, Callula Devina, that "representatives of companies or organizations to deal with the community".

Next, as many as 16 public perceived that the definition of public relations and Humas is a part of channeling information. "Public relations is someone who has the duty to transmit information, expose news and news" (Giri Ramdani). Strengthened by the opinion of Nafrizal as follows "Humas is a division that becomes a bridge between the committee and the community that will distribute information".

Seven other informants defined the function of public relations and Humas as the guardian of the company's good image. "What is clear is that public relations is to maintain the company's good image" (Karisma). Then, there were three other informants who argued that public relations and Humas were an important part of the company. "Public relations is an important part of the company" (Fernando Desma).

There were informants who stated that public relations and public relations have a duty as part of administration in an organization. "Public relations in educational institutions are like people in the administration department" (Amika).

Contrary to the opinion of the previous informants, 35 informants said that public relations and Humas have different definitions. Five informants stated that public relations is part of Humas, but not always public relations is Humas.

Ten informants further stated that the scope of public relations is wider than that of Humas. "Public relations has a wider scope because it includes external and internal, but, Humas is only external" (Rafa $\mathrm{R})$, while three informants others claimed that public relations was narrower than that of Humas. "Public relations has a narrower scope because it relates to individuals, while Humas has a more complex scope" (Haryo Kuncoro).

According to three other informants, Humas was a form of relationship activities with the community, but public relations was someone who carried out the relationship. "Public relations and Humas are different. Public relations is a person who carries out relations with society. However, Humas is a form of activity" (Fikri Azizi). Two other informants said that Humas was more about relations with the community, while public relations was more about communicating the company.

Two other informants also conveyed the difference in concepts between public relations and Humas. "Humas is relations with society, if public relations is an introduction to the public" (Arifin). Furthermore, Jordan conveyed the concept of public relations and Humas as follows "if public relations builds a good image, while public relations becomes the liaison of institutions" (Jordan Dimitri). Another informant said that public relations and Humas could differ depending on the company or institution being shaded (Yoshi Gema).

In contrast to other informants, Suroso, a mobile fried rice seller, said that "Humas is relations with the society in the framework of security like security guards (hansip and satpam)" (Suroso). Finally, Diva as a student stated that Humas was people who embrace and liaise between superiors and subordinates, but, she did not know the concept of public relations. Total of 24 informants admitted that they did not understand at all about public relations and Humas, while nine informants knew the concept and definition of Humas, but did not know or never even heard of public relations. 


\section{b. The functions of public relations and humas}

There were 77 informants who said that the functions of public relations and Humas were the same, namely establishing good relations and cooperation between the company and the community. One of the informants said, "Establish good relations between the company and the community" (Zaidan). Zaidan also stated that the function of public relations and Humas was to build good relations between the company and the community.

Furthermore, 28 informants argued that the functions of public relations and Humas were to collect messages or information and convey this information to the public. One of the informants who works as a nurse stated, "as a place to accommodate messages or information and convey the information to the public" (Lina).

Other informants also explained the function of public relations and Humas that "the function may be to provide information from the company or organization to the public, then they must also provide an overview of the organization to the public." (M. Iqbal Novianto). This is similar to what was said by another informant, Mezzaluna, that the function of Humas is as a bridge between individuals and institutions as well as channelling information. "The function of Humas is as a bridge between individuals and institutions. Apart from that, Humas also functions as a channel of information between certain parties" (Mezzaluna Putri).

The perception of public relations and Humas functions as guardian of the company's image, connecting with the community and building company branding was raised by 10 publics. One of the informants said that the function of public relations and Humas is to form a good image, namely "providing information about the organization and maintaining a positive image of the company" (Sugeng Sutrisno).

Next, six public informants perceived that public relations and Humas only have the function of forming a good organizational image in society, one of which was put forward by Luke, namely "Maintaining the image of the company itself" (Luke Oswald).

Several informants have different opinions. Like the five public informants who perceived the function of public relations and Humas as communicators with external parties, "yes, communication with external parties" (Agung Hartono). Three other informants argued that the function of public relations and Humas was to go directly to the field, namely "The function of Humas is to go directly to the field to control conditions" (Bayu). In line with Bayu, other informants also agreed with the function of Humas, "Humas has a wider scope than public relations, and Humas has the duty to go directly to the field" (Rafa R). Selly also stated the same thing, namely "Humas goes directly to the community" (Selly Ferbrina).

Meanwhile, some practitioners called public relations and Humas the same profession. Althea Kireina, practitioner from FISIP UB, answered that "In addition to building and maintaining public image, maintaining community relations, media relations, as well as handling crisis management and holding press conferences." Another thing that was also stated by Ibnu Pohan, Head of Information and Communication Center of FISIP UB, who said that Humas or public relations has the same function, "Create an image or branding image and keep or manage the image of the organization where he works".

Another practitioner, Nur Salam (Public relations of Polinema) also reinforced that public relations and Humas were the same profession. The function of public relations 
and Humas was to build relationships, build a good image for the company, and solve problems related to the image of the company. Public relations or Humas was considered as the front of an institution whose job it is to provide information to the public. "The function of a public relations officer is to inform a news activity or event in a particular institution, to maintain the image of the place where he works and to compile an activity report to be submitted to the protocol party" (Nur Salam).

It is interesting that there were practitioners who called public relations and Humas as different professions. Sutaman (Public Relations of UIN Malang) explained that the function of public relations tends to be more towards relationship communication, while Humas handles protocol, internal and external information, coordinates internal and external activities, and acts as a mediator in various internal conflicts. Sutaman's opinion that distinguishes public relations and Humas is also in line with the perception of Ulum (UM Humas) that "the function of Humas in government agencies provides answers to people who ask questions about these agencies, while public relations is almost the same as Humas on a wider scale, because public relations includes individuals, organizations and companies, while Humas is only within the scope of government".

Another practitioner who saw public relations and Humas as something different was Sumirah (Internal Communication at Merdeka University Malang). "Humas is more concerned with the inside of the campus, such as campus ambassadors, students who want to take part in competitions, campus seminars and others. The main function of this function is the internal part of the campus itself."

\section{c. Gender issues}

The public and practitioner tended to have the same perceptions toward public relations and Humas based on gender. A total of 86 informant explained that both men and women have the same opportunity to become public relations practitioners. Giri Ramdani said that "Public Relations does not emphasize on the gender because public relations is definitely about soft skills in communication". However, there are 18 people who perceived that public relations or Humas practitioners were more suitable for women because women are perceived to be more attractive than men. A different point was stated by six other informants who argued that a man was more suitable to carry out the role and function of a public relations or Humas practitioner because men have more rationality in a job. Interestingly, there are three informants who believed that Humas practitioners were more suitable to be run by a woman, while public relations practitioners are more suitable to be run by men. Other informants, totaling 40 people, answered they did not know.

From the practitioner's side, practitioners argued that all genders can become public relations practitioners, as long as they have credibility, skills or abilities. However, Santoso (Center for Information and Public Relations of Gajayana University) considered that "women are better suited to women because women are calmer, more tolerant and have better service to women but men's assertiveness is also very necessary in coordination and field affairs". Another opinion expressed by the informant who did not want to be named, "maybe for us men or women are the same, however, it is more flexible if public relations tends to women". 


\section{d. Educational Backgrounds}

Most of the public perceived that a background in communication and public relations is a priority for becoming a public relations or Humas practitioner. About 29 people believed that everyone can become a public relations officer because the most important thing in this field of public relations is to have good communication and public relations skills. Al Khas Syairul Niam said that "any background does not have to incline to which education. But it must be able to convey information to the outside, so it must have good grammar and it must be persuasive".

One of the respondents, Amika, 25 years old who worked as a kindergarten teacher, gave her argument that "Public relations is not necessarily chosen from a better graduate. So, in my opinion, it has advantages such as being responsible, thinking about positive things that are in them and people's views can also work well. Public relations have to think of plans when becoming a public relations".

Most of the practitioners, argue that the suitable educational background is communication science or PR itself, although in reality in the world of work, a public relations or PR practitioner does not have to be someone who also has a background in communications or PR itself. Communication science majors should be more suitable to be a public relations or PR practitioner but can be from any major. What is more important is to have competence in the field. Practitioners think that it is advisable for a public relations practitioner to have a communication background or public relations major because they already have the basics needed for practice.

\section{e. The competence of Public relations and Humas}

There were 22 informants answered that they did not know anything about what abilities a public relations and Humas practitioner should have. Eighteen other informants argued that the abilities a public relations practitioner should have is the ability to be attractive to the audience so they can get attention, are responsive, can speak well, and have high self-confidence. Good public speaking skills, communication skills and experience were chosen by 45 other people who thought of the suitable abilities for a public relations and Humas practitioner.

From the practitioner's point of view, Eko who was a practitioner of the Gajahyana University's information and public relations center, explained that practitioners must "have good spirituality, good integrity, be good at positioning themselves, have good communication skills and have an attractive personality". Eight other practitioners argued that having communication skills and being capable and insightful were important abilities that public relations or Humas practitioners should have.

There are two other practitioners who perceived that a public relations or Humas practitioner must be able to position himself as an intermediary in a company or be neutral, be able to update information and coordinate with internal and external parties well, and be close to superiors so that the public relations and Humas practitioner was able to run good information management (making magazines, tabloids, blogs), not forgetting the importance of being broad-minded, having an extrovert personality, and having a high social spirit and being sensitive to the environment and responsive in helping others. This is quite in line with the opinion of three other practitioners who explained 
the importance of being able to approach well with the audience and the community in order to be able to easily establish interactions and persuade the community.

Two other practitioners said that it was not only the communication skills needed by public relations and Humas practitioners, but appearance also deserves special attention. Sutaman said that "the practitioner must have a complete personality background, must master language communication, and be able to bridge". Through various views of informants, both public and practitioners, it can be concluded that in addition to communication skills, confidence, and attractive appearance, a public relations and Humas practitioner must also have other abilities that can support public relations and Humas works such as socializing, solving problems, having broad insight, the ability to write and see conditions and other supporting abilities.

\section{Build the Propositions}

From the data findings described above, the authors are able to formulate the following propositions:

1. Public perceptions toward public relations tend to be positive perceptions. Positive perceptions include, among other things, the perception that public relations or Humas practitioners are a profession that establishes good relations and cooperation between the company and the public, maintains the image of the organization, and as a place to accommodate messages or information and convey the information to the public.

2. Even though they tend to think of them as the same profession, some public and practitioners still consider public relations and Humas as different professions.

3. Although they tend to think of public relations as a profession that both men and women can do, a small proportion of the public and practitioners consider the public relations profession to be more suitable for women.

4. There is no difference between the public and practitioners regarding the educational background of a public relations practitioner. Most of them think that public relations practitioners should come from the disciplines of Communication Sciences and public relations.

\section{Discussions}

This study has succeeded in illustrating that there are positive developments regarding public acceptance of the public relations profession. The public and practitioners have very good perceptions of this profession. The authors believe that Edward Bernays' thoughts have been accepted by the public.

Bernays has offered the concept of public relations counsel, i.e. practitioners as management advisors. This concept develops public relations practice as an activity to help management interpret the public and help the public to interpret management. The concept of public relations counsel was offered by Bernays in response to the many propaganda that tended to be negative and manipulative. Bernays lays the foundation for professional communication practice. Previously, public relations as known today was more of a press-agentry nature and direct publicity. In the end, Bernays introduced the concept of new propaganda, which is balanced manipulation by paying attention to public approval and based on research and promoting ethical aspects through twoway interpretation (Culbertson et al., 1993; Grunig \& Hunt, 1984; Lamme \& Russell, 2010).

This positive public perceptions in this current research also seem to confirm some previous research that the practices of 
public relations in Indonesia have started to adopt a two-way symmetrical communication model, although there are still many asymmetrical two-way communication (Kriyantono et al., 2017; Kriyantono, 2019a). The two models are better than the press-agentry and public information models, which are still oneway communication (Bosley, 2010; Halff \& Gregory, 2014; Mundy, 2016).

The positive public perceptions are also possible due to the increasing implementation of the online public relations approach in public relations practice in Indonesia, both in business institutions and in government institutions, including state universities, such as the use of websites (Azhary et al., 2018; Elidjen, 2017; Idris, 2017; Kriyantono, 2020a). Today is the era of online or digital public relations (Verčič, Verčič, \& Sriramesh, 2015), which corresponds to the characteristics of most Indonesians who have entered the era of internet technology and industry 4.0 (Hidayanto \& Kartosapoetro, 2020; Shindita \& Mukaromah, 2020). In general, the internet has had a positive effect on government agencies in carrying out their service functions in the current democratic era (Ahmad, 2019; Androutsopoulou et al., 2019; El-Haddadeh et al., 2019; Mergel, 2019).

Regarding the media's great ability to influence and form public perceptions (Apuke, 2018; White \& Park, 2010), the digital public relations approach can help create long-term relationships between public relations and the media. The media is also able to form public perceptions with negative words and creates framing such as "public relations gimmick" and "public relations nightmare". This framing is called the second-level agenda setting (Kiousis et al.,2016; White \& Park, 2010). Through this long-term relationship, in the end, public relations is able to influence this media framing (Kiousis et al., 2006). As a result, the public's perception can be kept positive.

For the media, the use of websites as a means of disseminating information has proven to be very useful as a source of news for journalists and ultimately affects the quality of democracy ( Robinson, 2014; Suntai et al., 2018).

From the data findings, there are things that have apparently escaped the understanding of the public and practitioners. Nobody perceives public relations or Humas as a crisis manager, i.e. having the task of managing the crisis and as a profession that manages CSR (Corporate Social Responsibility) activities. In fact, in various literature, it is found that public relations practitioners, as the person in charge of communication management, play a vital role in crisis management (as crisis managers) (Cho \& Yeng-Hong, 2016; Anggraini \& Kriyantono, 2018; Claeys \& Cauberghe, 2015i Coombs, 2015; Indiraswari et al., 2018; Kriyantono, 2015).

The authors perceive that this is due to a lack of understanding that the crisis is actually caused by communication factors. This is based on the opinion that "faillure to communicate is one of the biggest mistakes you can make in a crisis situation" (Duke \& Masland, 2002, p. 31).

Then, CSR should be the responsibility of public relations or Humas practitioners (Kriyantono, 2019). CSR is an important factor in increasing the credibility of public relations (Shah \& Chen, 2010) and the reputation of the organization in times of crisis (Hai-Yan et al., 2012; Jeong, 2009).

The tendency of positive perceptions also proves that public relations has credibility in the minds of the public. If public relations does not have a credibility aspect, the public may choose not to trust the information conveyed by public relations (Callison, 2004). Especially for government agencies, if practitioners do 
not have credibility, it is very contrary to the main role of public relations as a facilitator of public information disclosure in the democratic era (Robertson, 2020; Tantivejakul, 2019).

In addition, the number of practitioners who perceive their profession positively, based on Self-Fulfilling Prophecy Theory (Merton, 1948), has the potential to make public relations activities that practitioners do more effective. "If men defines situations as real, they are real in their consequences." (Merton, 1948, p. 193). So, it can be concluded that the more positive the perception of work, the more positive the resulting performance.

This current research also produces propositions that some public and practitioners still perceive the public relations and Humas professions as different professions, although the majority tend to think of both terms as the same profession. The authors consider it a challenge to provide an understanding to the public that these two professions are the same, only in different terms. Public relations is in English, Humas is in Bahasa. Understanding of these two terms is important because, based on the SelfFulfilling Prophecy Theory, it can affect performance effectiveness. Kriyantono (2017b), using the measurement standard of Excellent Theory in Public Relations, has proven that practitioners who call themselves Humas are less excellent than practitioners who call themselves public relations.

From reviewing literature, the authors have found that the definition, function, and scope of public relations according to Western academic literature (such as Elving et al., 2012; Gregory, 2010; Grunig \& Hunt, 1984; Grunig, Grunig, \& Dozier, 2002; Heath , 2013; L'Etang, 2004; Lattimore et al., 2007) are in line with several ministerial regulations on public relations, such as
Regulation of the Minister of State Apparatus Empowerment-Bureaucratic Reform no 6 of 2014 concerning Public Relations Organizations ; Regulation of the Minister of Administrative and Bureaucratic Reform No. 30 of 2011 concerning General Guidelines for Public Relations Governance in Government Agencies; Permenpan-RB No. 31 of 2011 concerning General Guidelines for Public Relations Infrastructure in Community Institutions; Regulation of the Minister of Home Affairs No.13 of 2011; and Regulation of the Minister of Communication and Information Technology No. 35 of 2014 concerning the Public Relations Coordinating Board.

Both academic literature and the regulations define public relations or Humas as a management function in the field of information and communication that is persuasive, effective, and efficient, to create harmonious relationships with the public, to create a positive image and reputation. So, it can be said that public relations is another name for Humas.

Furthermore, the research has also led to the another proposition that, although the majority tends to regard public relations as a profession that both men and women can work, some of the public and practitioners consider the public relations profession to be more suitable for women. This finding shows that the development of democracy in Indonesia is getting better, which is one indicator, according to Nashriyah et al. (2020), is the reduction of gender discrimination. Moreover, public relations is a profession dominated by female workers (Erzikova \& Berger, 2016; Place \& Vanderman-Winter, 2018) or female concentrated and female dominated (Pompper \& Jung, 2013).

The last proposition claims that both public and practitioners tend to perceive that the education background of 
Communication Science and public relations plays a role in the success of public relations activities. This proposition further reinforces the findings of previous literature that public relations is multidisciplinary in nature (Greenwood, 2010; Kriyantono, 2017a, 2020b; Mundy, 2016; Sisco et al., 2011). In addition, the development of public relations started from a practical aspect (Horsley, 2009; Lamme \& Russel, 2010). The need for public relations theories for practical success is also recognized by practitioners in the US, Germany, Singapore, Australia and New Zealand (Wehmeier, 2009).

The data findings also show the practitioners' statement that many practitioners do not come from a communication science and public relations education background. This phenomenon is commonly known as encroachment, in which the field of public relations is filled by people who have no background in public relations, public relations is under the coordination of other divisions, or public relations functions are carried out by other departments (Papilaya et al., 2018).

Since theory is knowledge about the real world that is organized, thus helping people to visualize and explain something (Neuman, 2014), the authors believe that communication science graduates have theoretical capital that helps the practical application of public relations. According to Botan \& Hazleton, Jr (2006), there are four theoretical functions for public relations practitioners, namely the function of description (theory provides vocabulary for learning and explaining public relations concepts) which practitioners may not be familiar with; Understanding function (Theory functions to provide an understanding of public relations); Prediction and control functions (Theory has the ability to predict, control, and anticipate the possibilities of applying concepts). For example, if the organization does not apply the concept of boundary spanning, public relations practitioners can predict that this will affect the quality of relations with the public and cannot properly manage issues; Heuristic functions (theories are related to each other and are integrated with each other to be used to solve problems).

\section{Conclusion}

This study has confirmed the research assumption that public perceptions of the public relations profession tend to be positive. These results contribute to changing the previous view that public relations is considered an attempt at manipulating communication messages.

The research contribution can be seen from the four propositions offered, namely the public's perception of public relations practitioners tends to be a positive perception. Positive perceptions include, among others, the perception that public relations or public relations practitioners are a profession that maintains good relations and cooperation between the company and the public, maintains the image of the organization, and as a place to accommodate messages or information and convey this information to the public; Even though they tend to think of them as the same profession, some publics and practitioners still consider public relations and PR as different professions; Although they tend to think of public relations as a profession that both men and women can do, a minority of the public and practitioners consider the public relations profession to be more suitable for women; and there is no difference between the public and the practitioner regarding the educational background of a public relations practitioner. Most of them think that public relations practitioners should come from the disciplines

166


communication sciences and public relations. This study has confirmed the research assumption that public perceptions of the public relations profession tend to be positive. These results contribute to changing the previous view that public relations is considered an attempt at manipulating communication messages.

This study has confirmed the research assumption that public perceptions of the public relations profession tend to be positive. These results contribute to challenge the previous view that public relations is considered an attempt at manipulating communication messages.

However, the results of this study cannot be generalized in a context that includes all public relations activities in Indonesia. The limited number of informants and the low principle of informant representation make data generalization low. In addition, this study does not focus on investigating the effectiveness of public relations activities and only focuses on the description of public and practitioner perceptions.

Therefore, for further research, the authors recommend conducting survey research to evaluate the correlation of the four propositions. This includes examining the correlation between perceptual trends and the use of a digital public relations approach. In addition, the authors recommend examining the correlation between perceptions and quality of work of public relations practitioners.

\section{Acknowledgement}

The authors would like to thank the Faculty of Social and Political Sciences, Brawijaya University for providing grant funding to conduct this research. Thanks also go to Dymi and Kharisma, research assistants, who helped collect and code the data.

\section{References}

Ahmad, Z. A. (2019). Embracing social media: The change and disruption to public relations practices in Malaysia. Malaysian Journal of Communication, 35(1), 319-337. https://doi.org/10.17576/JKMJC-20193501-21

Alkazemi, M. F., \& Wanta, W. (2018). The effect of oil prices on the media agenda: A model of agenda building. Newspaper Research Journal, 39(2), 232-244.

https://doi.org/10.1177/0739532918775 655

Androutsopouloua, A., Karacapilidisb, N., Loukisa, E., \& Charalabidisa, Y. (2019). Transforming the communication between citizens and government through Al-guided chatbots. Government Information Quarterly, 36, 358-367.

https://doi.org/10.1016/j.giq.2018.10.0 01

Anggraini, C., \& Kriyantono, R. (2018). Communication media for public relations: Reading stakeholders' opinion on corporate social responsibility in Indonesia. RJOAS, 10(82), 171-186. https://doi.org/10.18551/rjoas.201810.19

Apuke, O. D. (2018). Understanding the concept of publicity in public relations: A synoptic review. Arabian Journal of Business \& Management Review, 7(2), 32-34.

Azhary, S., \& Kriyantono, R. (2018). Understanding of public relations officer towards transparency and accountability of information in online public relations implementation in public institutions. Pekommas, 3(2), 213-220.

http://dx.doi.org/10.30818/jpkm.2018. $\underline{2030210}$ 
Azhary, S., Kriyantono, R., \& Wulandari, M. P. (2017). The snapshot of online public relations in Indonesia public agencieseffort to comply with conditions of PITA: Quantitative study on content analysis of the websites of public agencies that receive public information transparency award in 2016. Wacana, 20(3), 135-144. https://wacana.ub.ac.id/index.php/wac ana/article/view/497

Bosley, C. (2014). Two-way symmetrical communication in a non-profit organization. (Master's thesis, San Diego State University). https://digitallibrary.sdsu.edu/islando ra/object/sdsu\%3A2924

Botan, C. H., \& Hazleton, V. (2006). The role of theory in public relations. In C.H. Botan \& V. Hazleton (Eds.), Public relations theory. New Jersey: Lawrence Erlbaum.

Broom, G M, \& Dozier, D. M. (1986). Advancement for public relations role models. Public Relations Review, 12(1), 37-56. https://doi.org/10.1016/S03638111(86)80039-X

Callison, C. (2004). The good, the bad, and the ugly: Perceptions of public relations practitioners. International Journal of Phytoremediation, 21(1), 371-389.

https://doi.org/10.1207/s1532754xjprr $1604 \_3$

Callison, C., Merle, P. F., \& Seltzer, T. (2014). Smart friendly liars: Public perception of public relations practitioners over time. Public Relations Review, 40(5), 829-831. https://doi.org/10.1016/j.pubrev.2014 .09 .003

Cho, S. \& Yeong-Hong, S. (2016). Journalists' evaluation of the South Korea government's crisis management in the Cheonan incident. Journal of Contingencies and
Crisis Management, 24(4), 222-229. https://doi.org/10.1111/1468-

5973.12117

Claeys, A. \& Cauberghe, V. (2015). The role

a favorable pre-crisis reputation inprotecting organizations during crises. Public relationss Review, 41, 6471.

https://doi.org/10.1016/j.pubrev.2014 .10 .013

Coombs, W.T. (2015). Crisis communication and its allied fields. Dalam The handbook of crisis communication. Coombs, W. T., \& Holladay, S. J. (Ed.). United Kingdom: Blackwell Publishing.

Culbertson, H.M., Jeffers, D.W., Stone, D.B., \& Terrell, M. (1993). Social, Political, and Economic Contexts in Public Relations: Theory and Cases. New Jersey: Lawrence Erlbaum.

Daymon, C. \& Holloway, I. (2011). Qualitative Research Methods in Public Relations and Marketing Communications (Second Ed). London: Routledge

Duke, S., \& Masland, L. (2002). Crisis communication by the book. Public Relations Quarterly, 47(3), 30-35.

El-Haddadeh, R., Weerakkody, V., Osmania, M., Thakkerc, D., \& Kapoor, K. K. (2019). Examining citizens' perceived value of internet of things technologies in facilitating public sector services engagement. Government Information Quarterly, 36 , 310-320. https://doi.org/10.1016/j.giq.2018.09. $\underline{009}$

Elidjen, A. P. (2017). Evaluating the implementation of public information disclosure on the official website of Indonesian ministries. Procedia Computer Science, 116, 54-60. https://doi.org/10.1016/j.procs.2017.1 $\underline{0.008}$ 
Elving, W., Ruler, B. v., Goodman, M., Genest, C. (2012). Communication management in The Netherlands Trends, developments, and benchmark with US study. Journal of Communication Management, 16(2), 112-130.

https://doi.org/10.1108/136325412112 17551

Erzikova, E., \& Berger, B. K. (2016). Gender effect in Russian public relations: $A$ perfect storm of obstacles for women. Women's Studies International Forum, 56, 28-36. https://doi.org/10.1016/j.wsif.2016.02 .011

Fullerton, J. A., \& Mckinnon, L. M. (2015). US public relations students' perceptions of $P R$ : What college students think about $P R$ education and the $P R$ profession. Public Relations Journal, 9(2), 1-17. https://prjournal.instituteforpr.org/w pcontent/uploads/2015vogno2Fullerto nMcKinnon.pdf

Gower, K. K. (2006). Public relations research at the crossroads. Journal of Public Relations Research, 18 (2), 177190.

https://doi.org/10.1207/s1532754xjprr1 $\underline{8026}$

Greener, T. (1995). Kiat sukses public relations dan pembentukan citra. Jakarta: Bumi Aksara.

Gregory, A. (2010). Planning and managing public relations campaigns: A strategic approach. London: Kogan Page.

Greenwood, C.A. (2010). Evolutionary theory: The missing link for conseptualizing public relations. Journal of Publis Relations Reserach, $22 \quad$ (4), 456-476. https://www.tandfonline.com/doi/abs/ 10.1080/10627261003801438

Grunig, J. E., \& Grunig, L. A. (2002). Models of public relations and communication (J. E. Grunig, ed.). NJ: Lawrence Erlbaum.

Grunig, J.E., \& Hunt, T. (1984). Managing Public Relations. New York: Holt, Rinehart \& Winston, Inc.

Haidayanto, H., Amezaga, T. R. W., \& Silva, B. O. (2012). Corporate social responsibility perspectives and practices in Chinese companies: A brief overview on environment, consumers and external communication. Journal of Management and Sustainability, 2(1), 57-66. DOI: 10.5539/jms.v2n1p 57

Halff, G., \& Gregory, A. (2014). Toward an historically informed Asian model of public relations. Public Relation Review, 40, 397-407. https://doi.org/10.1016/j.pubrev.2014 .02 .028

Heath, R. L., \& Coombs, W. T. (2006). Today's Public Relations: An Introduction. California: Sage.

Heath, R. L. (2013). Encyclopedia of Public Relations. California: Sage Publications, Inc.

Hidayanto, S., \& Kartosapoetro, I. S. (2020). Strategi digital branding pada startup social crowdfunding: Studi kasus pada kitabisa.com. Jurnal KOMUNIKATIF, 9(1), 19-33. https://doi.org/10.33508/jk.vgi1.2259

Horsley, J.S. (2009). Women's contributions to American public relations, 1940-1970. Journal of Communication Management, 13(2), 100-115.

https://doi.org/10.1108/13632540910 951731

Idris, I. K. (2017). Government social media in Indonesia: Just another information dissemination tool. Malaysian Journal of Communication. 34(4), 337-356. https://doi.org/10.17576/JKMJC-20183404-20 
Indiraswari, R., Kriyantono, R., \& Wulandari, M. P. (2019). Crisis domination and crisis responses strategies of Indonesia state-owned companies online media during January 2007-July 2018. RJOAS, 6(90), 276-281. DOl10.18551/rjoas.201906.34

Jeong, S.H. (2009). Public's responses to an oil spill accident: A test of the attribution theory and situational crisis communication theory. Public Relations Review, 35, 307-309. https://doi.org/10.1016/j.pubrev.2009. 03.010

Kiousis, S., Ragas, M. W., Kim, J. Y., Schweichart, T., Neil, J., \& Kochhar, S. (2016). Presidential agenda building and policymaking: Examining linkages across three levels. International Journal of Strategic Communication, 10(1), 1-17. https://doi.org/10.1080/1553118X.201 5.1090441

Kiousis, S., Mitrook, M., Wu, X., \& Seltzer, T. (2006). First-and second-level agenda building and agenda setting effects: Exploring the linkages among candidate news releases, media coverage, and public opinion during the 2002 Florida Gubernatorial Election. Journal of Public Relations Research, 18 (3), 265-285. https://doi.org/10.1207/s1532754xjprr $\underline{1803-4}$

Kriyantono, R. (2020c). Teknik praktis riset komunikasi kuantitatif dan kualitatif. Jakarta: Prenada.

Kriyantono, R., \& Rakhmawati, F. (2020). A qualitative research on the use of fashion for public relations practitioners as a presentation of self-image. Jurnal Social dan Humaniora, 10(1). http://dx.doi.org/10.31940/soshum.v 10i1.1446
Kriyantono, R., \& McKenna, B. (2019) Crisis response vs crisis cluster: a test of situational crisis communication theory on two crisis clusters in Indonesian public relations. Jurnal Komunikasi; Malaysian Journal of Communication, $35 \quad$ (1), 222-236. https://doi.org/10.17576/JKMJC-20193501-15

Kriyantono, R. (2019a). Public relations activities of state universities based on the excellence theory. Avant Garde, $\quad 7(2), \quad$ 154-170. http://dx.doi.org/10.3608o/ag.v7i2.90 $\underline{1}$

Kriyantono, R. (2019b). Peran manajerial praktisi humas perempuan lembaga pemerintah dalam profesi yang didominasi perempuan. Jurnal Studi Komunikasi dan Media, 23(2), 181-194. http://dx.doi.org/10.31445/jskm.2019. 2694

Kriyantono, R. (2019c). Syntactic analysis on the consistency of Jokowi's rhetorical strategy as president and presidential candidate. Journal of Applied Studies in Language, 3(2), 127139.

http://dx.doi.org/10.31940/jasl.v3i2.1 419

Kriyantono, R. (2019d). Research strategies and media relations in public relations. Jurnal KOMUNIKATIF, 8(2), 178-19o.

https://doi.org/10.33508/jk.v8i2

Kriyantono, R. (2019e). Apologia strategies and ethical aspects of government public relations in a crisis situation. Jurnal Representamen, 5(2), 32-41. https://doi.org/10.30996/representa men.v5io2.2937

Kriyantono, R. (2019f). Persepsi praktisi humas dan masyarakat terhadap program tanggung jawab sosial perusahaan. Jurnal Kajian Ruang Sosial Budaya, 3(2), 14-37. DOI: 
10.21776/ub.sosiologi.jkrsb.2019.003. $\underline{2.03}$

Kriyantono, R. \& Sa'diyah, H. (2018). Kearifan lokal dan strategi komunikasi public relations di BUMN dan perusahaan swasta. Jurnal Ilmu Komunikasi, 15(20), 171-188. https://doi.org/10.24002/jik.v15i2.148 o

Kriyantono, R. \& McKenna, B. (2017). Developing a culturally-relevenat public relations theoty for Indonesia. Malaysian Journal of Communication, 33(1), 1-16. https://doi.org/10.17576/JKMJC-20173301-01

Kriyantono, R. (2017a). Teori public relationss perspektif barat \& lokal aplikasi penelitian dan praktik. Jakarta: Kencana.

Kriyantono, R. (2017b). Do the different terms affect the roles? A measurement of excellent and managerial role of business and government public relations practices in Indonesia. International Journal of Applied \& Business Research, 15(6), 193-209.

https://serialsjournals.com/index.php ?route=product/product/volumearticl e\&issue $i d=115$ \&product $i d=343$

Kriyantono, R., Destrity, N. A., Amrullah, A. A. \& Rakhmawati, F. Y. (2017). Management of Public Relations for Supporting The Anti-Corruption National Program in Indonesia. International Journal of Applied Business \& Economic Research, 15(20), 293-313.

https://serialsjournals.com/abstract/7 5702_24.pdf

Kriyantono, R., Amrullah, A. A., Destrity., N. A. (2017). The model of public relations practices in Indonesia. Global Journal of Business and Social Science Review, 5(3), 194-199. https://papers.ssrn.com/sol3/papers.c fm?abstract_id $=3017683$

Kriyantono, R., Riani, Y. A., \& Savitri, R. I. (2017). Public's attribution vs punitive behavior in Indonesian public relations practices. Jurnal Ilmu Komunikasi, 14(1), 43-60. https://doi.org/10.24002/jik.v14i1.118 o

Kriyantono, R. (2015a). Contemporary rhetoric deconstructs rhetorical approach in public relations research development. International Journal of Development Research, 5(6), 48194825.

Kriyantono, R. (2015a). Kontruksi humas dalam tata kelola komunikasi lembaga pendidikan tinggi di era keterbukaan informasi publik. Jurnal Pekommas, 18(2), 117-126. http://dx.doi.org/10.30818/jpkm.2015 .1180205

Kriyantono, R. (2015b). Public relationss \& crisis management. Jakarta: Kencana Prenada Media.

Kriyantono, R. (2015). Public Relations and Corporate Social Responsibility in Mandatory Approach Era in Indonesia. Procedia-Social Behavioral Sciences, 211, 320-327. https://doi.org/10.1016/j.sbspro.2015. 11.041

Kyrychok, A. P. (2017). An impact of Situational crisis-communication theory on the efficiency of investigations in the field of crisis communications. Science and Education a New Dimension. Humanities and Social Sciences, V(19), 55-58.

https://seanewdim.com/uploads/3/4/ 5/1/34511564/a._p._kyrychok_an_imp act_of_situational_crisiscommunication_theory_on_the_ef ficiency_of_investigations_in_the_fi eld_of_crisis_communications.pdf 
Lamme, M.O., \& Russell, K.M. (2010). Removing the spin: Toward a new theory of public relations history, Journalism and Communication Monographs, 11(4). https://doi.org/10.1177/152263791001 100402

Lattimore, D., Baskin, O., Heiman, S., \& Toth, E. (2007). Public Relations: The Profession and the Practice. New York: McGraw-Hill.

Littlejohn, S. W., Foss., K. A., \& Oetzel, J. G. (2017) Theories of human communication. (11 ${ }^{\text {th }}$ Ed). Illinois: Waveland Press.

L'Etang, J. (2004). Public Relations in Britain: A History of Professional Practice in the $20^{\text {th }}$ Century. London: Lawrence Erlbaum

Mergel, I., Edelmann, N., \& Haug, N. (2019). Defining digital transformation: Results from expert interviews. Government Information Quarterly, 36(4), 1-16. https://doi.org/10.1016/j.giq.2019.06. $\underline{002}$

Merton, R. K. (1948). The Self-Fulfilling Prophecy. The Antioch Review, 8(2), 193-210.

http://dx.doi.org/10.2307/4609267

Miles, M. B., Huberman, A. M., \& Saldaana, J. (2014). Qualtitative Data Analysis: A Methods Source Book. California: Sage.

Mundy, D. E. (2016). Bridging the divide: A multidisciplinary analysis of diversity research and the implications for public relations. Research Journal of the Institute for Public Relations, 3(1), 1-28.

https://prjournal.instituteforpr.org/w p-content/uploads/Dean-Mundy-11.pdf

Nashriyah., Maulida, R., Ningsih, Y. S., \& Yusuf, Y. Q. (2020). Addressing gender bias issues in elementary school EFL textbook: An analysis of grow with English. Humanities \& Social Sciences Reviews, 8(3), 56-63. https://doi.org/10.18510/hssr.2020.83 Z

Neuman, W. L. (2014). Social Research Methods: Qualitative and Quantitative Approaches. Essex: Pearson Education.

Papilaya, D., Kriyantono, R., \& Wulandari, M. P. (2018). Level of encroachment effect to excellent public relations: $A$ study on communication leaders activity at PT Telkom Indonesia. RJOAS, 4(76), 213-219. https://doi.org/10.18551/rjoas.2018$\underline{04.22}$

Pasadeos, Y., Berger, B., \& Renfro, R. B. (2010). Public relations as a maturing discipline: An update on research networks. Journal of Public Relations Research, $22 \quad$ (2), 136-158. https://doi.org/10.1080/10627261003 $\underline{601390}$

Place, K. R., \& Vanderman-Winter, J. (2018). Where are the women? An examination of research on women and leadership in public relations. Public Relations Review, 44, 165-173. https://doi.org/10.1108/JCOM-112019-0143

Pompper, D., \& Jung, T. (2013). Outnumbered yet still on top, but for how long?" Theorizing about men working in the feminized field of public relations. Public Relations Review, 39, 497-506. https://doi.org/10.1016/j.pubrev.2013. $\underline{08.007}$

Robertson, C. (2020). Rethinking public relations. Persuasion, democracy and society. Kevin Moloney and Conor McGrath Routledge. https://doi.org/10.1002/pa.2181

Robinson, K. (2014). Information subsidies and social media: The effect of news 
value presence on social media conversation. Virginia: Virginia Tech, Grunig PRIME Research Fellow. https://instituteforpr.org/wpcontent/uploads/Robinson-researchpaper.pdf

Shah, M. H., \& Chen, X. (2010). Advertising wounds, public relations cure: Corporate social responsibility perspective in China. International Journal of Business \& Social Science, 1(2), 137-153. ijbssnet.com/journals/Vol._1_No._2 November 2010/11.pdf

Simorangkir, D. N. (2013). Lookism in Indonesia's public relations industry. Women's Studies International Forum, 40, 111-120. https://doi.org/10.1016/j.wsif.2013.05 .014

Shindita, N. S., \& Mukaromah. (2020). Etika komunikasi dan interaksionisme simbolik pada anggota akun draft sms di media sosial. Jurnal KOMUNIKATIF, 9(1), 74-92. https://doi.org/10.33508/jk.v9i1

Sisco, H.F., Collins, E.L., \& Zoch, L.M. (2011). Breadth or depth? A content analysis of the use of public relations theory. Public Relations Review, 37, 145-150.

https://doi.org/10.1016/j.pubrev.2010 .10 .006

Suntai, D. I., Agbu, A.D., \& Targema, T. D. (2018). Mass media, freedom of expression and democracy: The Nigerian experience from 1999-2017. TSU Journal of Communication and Media Studies, 1(1), 102-113.

Tantivejakul, N. (2019). The never changing story: Eight decades of the government public relations department of Thailand. Public Relations Review, 45, 258-266. https://doi.org/10.1016/j.pubrev.2018 .08 .009
Tanyıldızı, N., \& Ataykaya, M. (2019). The perception of public relations profession in the Society: Example of Elazığ City. OPUS Uluslararası Toplum Araştırmaları Dergisi. https://doi.org/10.26466/opus.545791

Toth, E.L. (1992). The case of pluralistic studies of public relations: Rhetorical, critical and systems perspectives. In E.L Toth \& R.L. Heath (Eds.), Rhetorical and Critical Approaches to Public Relations (pp. 3-16). Hillsdale, NJ: Lawrence Erlbaum.

Verčič, D., Verčič, A. T., \& Sriramesh, K. (2015). Looking for digital in public relations. Public Relations Review, 41(2), 142-152. https://doi.org/10.1016/j.pubrev.2014 .12 .002

Wehmeier, S. (2009). Out of the fog and into the future: Directions of public relations, theory building, research and practice. Canadian Journal of Communication, 34(2), 265-282.

https://www.cjc-

online.ca/index.php/journal/article/ view/2033/3049

White, C., \& Park, J. (2010). Public perceptions of public relations. Public Relations Review, 36(4), 319-324. https://doi.org/10.1016/j.pubrev.2010 .09 .002

Yaxley, H. M. L. (2013). Career experiences of women in British public relations (1970-1989. Public Relations Review, $39,156-165$. https://doi.org/10.1016/j.pubrev.2013. 03.009 